\title{
Analysis of Value Inheritance, Preservation and Utilization of Chinese Traditional Settlement
}

\author{
Yi Zheng ${ }^{1, a}$ and Li Dong ${ }^{2, b^{*}}$ \\ ${ }^{1}$ Hubei University of Education, Wuhan, Hubei 430205, China \\ ${ }^{2}$ Wuhan University of Science and Technology, Wuhan, Hubei 430065, China \\ a57653123@qq.com, bsuper_dongli@sina.com \\ *The corresponding author
}

Keywords: Traditional settlement; Value inheritance; Preservation; Utilization

\begin{abstract}
With a long history, various forms, elaborate layout, profound value and folk culture, Chinese traditional settlement plays a role of the carrier of traditional culture, the representative of residential science, the fossil of sociological and the miracle of architectural art. However, in the meantime, it encounters problems of inheritance and preservation, and only by developing and protecting traditional settlement from government investment, value publicity, public participation and other aspects can it gain rebirth.

Introduction

The word "settlement" refers to villages, as recorded in Chinese "Book of Han Annals of Rivers and Canals": "Sometimes, if there are no any disasters in a place, more and more people will build houses here, thus leading to a village." It is a generic term of all kinds of localities of human, which not only is simply the aggregation of houses and buildings, but includes other living facilities and production equipment directly related to residence. Settlement is both places for dwelling, living, rest and different social activities and ground for human production.
\end{abstract}

\section{Types of Chinese Traditional Settlement}

Our nation has a vast territory and a long history. Traditional settlement remained with the form of physical symbols is, first, tangible property and sign, then memory of the nation, and product tied with geographical environment, climate characteristics, economic condition and humanistic background during the course of evolution of traditions. As an entity that carries human and human, human and nature, and human and society, traditional settlement falls into following classifications:

Structural Spaces with Ancestral Hall, Temple, Academy or Other Landmark Buildings as the "Point". The ancients advocate relations of "middle" and "center", and none of "sight in the world", "Nine-grade System" and the theory that the center of a residential area is the best place to live in fail to show the significance of "center". Therefore, people usually adopt mode of centripetal layout with a mountain, a pool, a house or a tree as its center to organize spaces and architectures and emphasize the centrality of settlement environment to build cohesive, balance and peaceful environmental atmosphere. Anhui, Hong Village can be used as a typical example(Fig.1) .

Organizational Structure with Mountains and Rivers as the "Line". In spatial structure and organization of traditional settlement, linear layout with surrounding mountains and crooked rivers is most utilized to construct flexible and changeable spatial structure. Extension of road is to control the spreading direction of settlement space, and network of streets and lanes is to build the developing framework of the internal space of settlement. A typical example is Zhang Guying Ancient Village that lies at the foot of Weidong Bijia Mountain to the east of Yueyang, Hunan(Fig.2) .

Structure with Large-scale Enclosed Architectures as "Plane". Planes of traditional settlement from rivers and woods to fences and walls all form enclosed space in accordance with different requirements. Traditional settlement space values enclosed pattern of geomantic theory, so traditional 
settlement is usually located at closed area embraced by mountains and rounded by rivers, forming a dwelling environment with mountains and rivers around. There are lots of settlements building walls out of safety and protection, thus enclosed settlements coming into being. A typical example is Hakka earthen buildings in Fujian.

In the long course of history, traditional settlement has gradually presented various forms of settlements in different places. Such kind of traditional settlement and buildings have been stamped with features of geographical environment, with strong characteristics of Chinese traditional culture, reflecting people's clothing, food, housing, transportation and other living conditions as well as politics, economy, etiquette, productivity, customs and other social conditions. It is a typical example of ethnic and regional culture and contains abundant value.

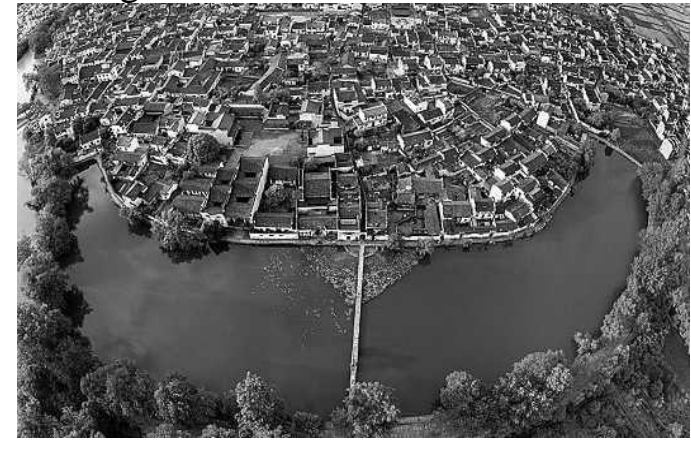

Figure 1. Aerial view of Hongcun Anhui

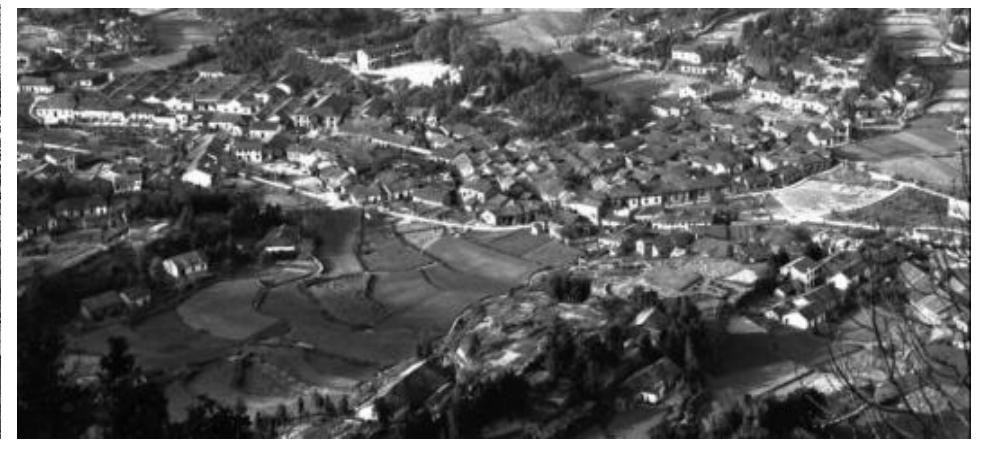

Figure 2. Aerial view of Zhangguying Hunan

\section{Value Inheritance of Chinese Traditional Settlement}

Chinese traditional settlement bears a long standing of history. It is the carrier of traditional culture, the symbol of residential science, the fossil of sociology and the miracle of architectural art.

Inheritance of Aesthetic Value. Beauty of order flows in settlement buildings. In group environment, generally, settlement serves as background architecture, while temples, ancestral halls and stages are main buildings. The two are apparently distinct from each other in size, so it is not recommended that settlement is too high or too big, but it should be built by measuring the range of human activities and valuing comfort. In terms of color, due to constraint by feudal code, it is forbidden to paint settlement buildings yellow, and most of settlements are built with grey bricks, black tiles and white walls. This technique that emphasizes rational arrangement order goes after a kind of "order of etiquette system". To organically bond the form of beauty with people's daily life is able to endow settlement with meaning of life.

It is common to see the beauty of unity and opposite in traditional settlement architectures. Form of Chinese traditional settlement is plentiful but not miscellaneous, ingenious but not feigned. Similar material, plane structure and space composition of settlement in a region tend to be the same in color, texture and image, which shows "a sense of convergence" of a regional settlement. However, convergence is never the same. It gives expression to changing forms with similarity. They pay attention to harmony in comparison and rhythm in change.

Beauty of mutual promotion between the void and the solid is presented in space construction of settlement architecture. Courtyard walls outside houses are decorated with hollow window, making the view of the whole courtyard between separation and non-separation. Through the hollow windows, people can see the scene of central yard and even backyard, adding serene beauty. Interior architectures are most divided by partition board, cover, screen and antique shelf for visual effect of "separated but not independent". Rooms can borrow scenery from each other to enrich indoor space, realizing an artistic effect of mutual promotion between the void and the solid.

Inheritance of Scientific Value. Out of users' demands, during practice, ancestors have developed a full set of methods of settlement architecture that fit local geographic conditions. Construction methods, including adjustment to local conditions, choosing preferable area to build houses, using local materials and proper consumption of materials, contain scientific construction theory and plain 
ecological awareness, for example, prior to site selection and construction, it is needed to obverse the environment, and strive to "back against mountain and face to rivers", "back against Yin and face to Yang" so as to guarantee abundant sunshine, properly use water sources available and take full advantage of natural environment to get access to resources required for human settlement. Enclosure of mountains, closeness of water and combination of plants maintain stability of microclimate. Skillful utilization of landform effectively saves land resources. With different terrain and landscape, architectural structures in different places are various, for example, architectures of Ganlan Style are built by mountains. Situated in complex landform, architectural structures like stilted buildings are used to fit different terrain to protect residents' living space from troubles of moisture, snake and ant. Skylight constructed in settlement of southern Anhui has the function of lighting, airing, ventilation. Courtyard space in quadrangle dwellings can serve as a place to grow trees and flowers and an area for basking, resting and communication, satisfying people's need of spiritual exchange.

Inheritance of Traditional Cultural Value. As the carrier of traditional culture, settlements give evidence to colorful ethnic culture, cohere with local conditions, folk customs and native flavor, and also send forth cultural spirit and temperament of Confucianism, Taoism and Dhyana Sect, for example, in southern Anhui, architectures present geomantic omen, which can be seen from its location near mountains and by rivers, and its respect of mountains, rivers and other natural features. Architectures are integrated with mountains and rivers, realizing the thought of unity of nature and man and identity of external environment and architectures themselves; the Eight Diagrams comprising Fujian earthen buildings lie in places selected. Architectures whose location is selected by the Eight Diagrams before construction are expected to have the function of stabilizing houses and counteracting evil forces. The process pursues harmony of heaven, earth and man, and puts emphasis on isostructuralism between man and matter plus thought of center-oriented, delivering Chinese traditional ethical code through earthen building spaces of and architectural ornaments (Fig.3), for example, the principal rooms, symbol of power and status and lived by owners, are built on the principal axis, and most face south.

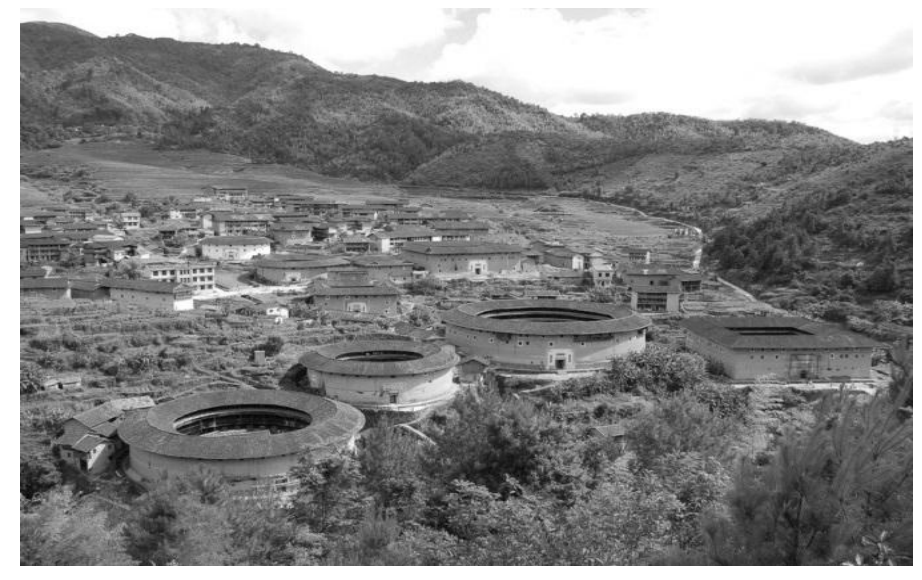

Figure 3. Square and circular planar pattern of Fujian earthen buildings

Inheritance of Ecological Inhabitation Value. Owing to influence of geographical factors, following the law of original ecology, mixed with idea of ecological housing, adjusting to local conditions, settlements of our country are built near mountains and by rivers, for example, because of the climate that summer is hot and winter is chilly with serious sandstorm, the overall design of courtyard houses of Beijing and Tianjin style adopts the layout that courtyard is surrounded by houses, reducing invasion of cold air and playing an important part in energy saving and windbreak. In accordance with local geographical conditions, water-supply system of Hong Village in Anhui manages to provide convenience for villagers' production, living and fire demand. By installing water-supply and drainage system throughout the village, it is successful adjusting temperature and environment of the village.

These traditional settlements not only present Chinese traditional philosophical thought that man is an integral part of nature, but show yearning and respect toward nature. Traditional settlements build harmonious surroundings and express features of human utilizing nature, changing nature and 
respecting nature. The traditional idea that "those living on a mountain live off the mountain, and those living near water live off the water" makes traditional settlements follow the rule of ecological construction of learning from nature.

\section{Protection of Chinese Traditional Settlement}

Traditional settlements entitled with "architecture without architect" has unique architectural style, profound historical appeal and high research value. How settlement is preserved and developed is to protect and inherit traditional culture, and is also an important proposition about utilization of historical architectural culture in the process of urbanization in our country.

Enhance Planning and Control, Conduct Inhabitant Protection. With further progress of urbanization, development of social economy, improvement of people's living standards, demands for culture of the whole society have been intensified, so people's awareness of protection and development of traditional settlement is awakening. To protect traditional settlement to the best needs to strengthen scientific planning and be strict to control of illegal construction. According to the basic thought of "functional complementation and proper layout", it is asked to combine with practical characteristics to present local features. In addition, it is necessary to carry through preservation of historical towns, ancient villages and old streets, protect and display style and features of historical culture and remain regional characteristics as much.

Update Residents' Awareness, Elevate Residents' Image. With social development, people's living standards are improving. Dwelling environment of traditional settlement cannot satisfy their demands, which need to address the problems of both material and spiritual civilization and lead residents to necessary reconstruction and expansion of hardware. This involves material selection, space layout and other problems. Government can file and publish directory of traditional villages, and carry out discrimination, sort, grading, classified protection and level-to-level administration. At the same time, it is essential to manage software-related work and adopt various methods to pass residents knowledge about protection and promotion of customs and heritage so as to realize continuation of residents and architectural culture.

Program Human Settlement, Improve Living Conditions. Comparatively speaking, more complete ancient settlements preserved are likely to lie in remote and out-of-the-way area, where economy is backward, natural environment better, but degree of modernization is leaving behind, and people's living standards are lower. Therefore, functional government departments need to formulate unified and scientific plans and strive to improve living conditions without any destroy of settlement characteristics, especially to handle relations between environmental protection and production development, thus providing a preferable settlement environment for protection and inheritance of traditional settlement. By use of advertising and education, residents shall realize that housing is not a shelter from wind and rain any more, but a kind of lifestyle. People should not only build houses to live in, but pay attention to environment and services.

\section{Utilization of Chinese Traditional Settlement}

Traditional settlement is memory of historical culture and also carrier of national gene. For a city, recovering traditional settlement is able to not only arouse public knowledge, acceptance and devotion about Chinese traditional culture, but enrich city spirit, excite positive energy and strengthen soft power.

Utilization of Handicraft industry of Traditional Settlement. Since antient times, China has been powerful in handicraft industry. A history of thousands of years gives birth to long culture, abundant handicraft skills and inheritors. Therefore, it is useful to rely on local inheritors of handicraft techniques to strive to develop handicraft products related to ancient settlement, such as wood-carving, brick-sculpture, stone-carving, wax printing, weaving, ceramics and other soft decoration handiwork, which can not only stimulate employment of local labors, but increases fiscal revenue for local government. 
Utilization of Food Culture of Traditional Settlement. One of the major businesses among handicraftsmen is catering. Food culture is an important component of Chinese traditional culture. Local government and department of culture may dig into tea culture, alcoholic culture and catering culture related to traditional settlement, and then develop relevant brand-name products to promote in local area an internet, which not only increases income of residents, but creates a platform for marketing of local tourism culture.

Utilization of Architectural Culture of Traditional Settlement. Traditional architecture is the miniature of historical culture. Especially, antient villages, old settlement, historic street, relevant customs and cultural relics and architecture with historical and cultural value, all of them show special charm of local history. For traditional settlement, local government should make a proper arrangement and sufficient planning, and give more special funds and policy support. To introduce cultural projects in a fair, just and open way is able to, on one hand, make a full use of nongovernmental capital and other social resources to expand supply channel of public culture and provide people richer cultural services, on the other hand, realize changes to public benefit, openness and sustainability, giving a brand-new appearance for relics and architectures in both contents and form, breaking a new path of preservation and utilization of relics and architectures, plus diversified investment in society, which can pave the way for developing tourism industrial belt.

\section{Summary}

Process of urbanization is an inevitable trend for social and historical development. As the course accelerates nowadays, we are changing every moment. Therefore, inheritance and preservation of traditional settlement have to be in line with new demands and changes of the time. It is essential to associate preservation and inheritance with government functions, social supervision and public participation. Meanwhile, it is needed to lay down specific laws and regulations to provide favorable external environment and basic security for settlement preservation. How settlement is preserved and developed is to protect and inherit traditional culture, and is also an important proposition about utilization of historical architectural culture in the process of urbanization in our country.

\section{Acknowledgements}

This Project Supported by the National Social Science Foundation of China(Grant No. 15CG156).

\section{References}

[1] Yang Gui-qing. Integrated Characteristics of Space and Social Significance of Traditional Chinese Settlements [J].Tongji University Social Science Section, Vol. 25(2014), No.3, p.60-67 (in Chinese)

[2] Ye Zu-run. Modem Residential Environment \& Traditional Inhabitable Culture [J]. Architectural Journal,Vol. 10(2001), No.12, p.21-23 (in Chinese)

[3] Wang Song. On the value and protection of Chinese traditional residence [J]. Housing Industry,(2008), No.7, p.43-45 (in Chinese)

[4] Sun Shi-sheng. The Traditional Residential Architectures and the Strategy of Ecologically Sustained Residential Architectures[J].Jourrnal of Wuhu Professional Technology College,Vol.5 (2003), No.4, p.85-87(in Chinese)

[5] Mo Lin-yu. To Protect the Authenticity of Ancient Cultural Tourism Development Model Under the Update[J].SiChuan Architecture,Vol.31 (2011), No.1, p.34-35(in Chinese)

[6] Wang Xiao-yang, Zhao Zhi-feng. The Conversion of Traditional Vernacular Village by Tourism[J].Architectural Journal,(2001), No.9, p.8-12(in Chinese) 
[7] Zhou Jian, Zhang Kai. The Building Classification and Protection Measurements in the Preservation Planning for the Historical and Cultural Heritage[J].City Planning Review,Vol.25(2001), No.1, p.38-42(in Chinese)

[8] Gu Xiao-juan, Yang Hong. Inspiration of Traditional Dwellings to the Innovation of Contemporary Ecological Architecture Design[A].Proceedings of the 17th Annual Conference of Chinese Vernacular Dwellings[C],Henan Kaifeng, (2009), p.252-256(in Chinese)

[9] Pu Xin-cheng. A Study on the Quantitative Method of Traditional Rural Settlement [M].Nanjing: Southeast University press,(2013), (in Chinese)

[10] Klaus Daniels. The Technology of Ecological Building: Basic Principles and Measures, Examples and Ideas[M].Boston: Birkhauser Verlag,(1994) 